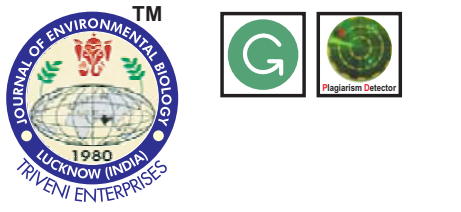

\title{
Field evaluation of synthetic kairomonal attractants against major lepidopteran pests of castor
}

Authors Info

\section{P. Duraimurugan ${ }^{1 *}$, M. Sampathkumar ${ }^{2}$ and P. S. Srinivas ${ }^{1}$}

${ }^{1}$ Crop Protection Section, ICAR-Indian Institute of Oilseeds Research, Hyderabad-500 030, India

${ }^{2}$ Crop Protection Section, ICAR-Indian Institute of Rice Research, Hyderabad-500 030, India

*Corresponding Author Email : duraimuruganp@rediffmail.com

Key words

Achaea janata Electroantennogram Lepidopteran pests Ricinus communis Synthetic kairomones

Publication Info

Paper received : 12.04.2017

Revised received: 14.06.2017 Re-revised received : 22.06.2017 Accepted : 24.06.2017

\begin{abstract}
Aim : The tobacco caterpillar (Spodoptera litura F.), semilooper (Achaea janata L.) and capsule borer (Conogethes punctiferalis Guenee) are the most destructive lepidopteran insect pests of castor. Developing new environmentally benign alternative monitoring and management system for these pests may reduce the frequency of application of insecticides and impact on the environment. Therefore, the objective of the present study was to evaluate the attractiveness of synthetic kairomones against these lepidopteran pests under laboratory and field conditions.
\end{abstract}

Methodology : Antennal responses of lepidopteran species to six synthetic kairomones (benzaldehyde, benzyl acetate, p-anisaldehyde, phenyl acetaldehyde, 2-phenyl ethanol and methyl salicylate) were studied by electroantennogram (EAG). Lures of three synthetic kairomones elicited strong EAG responses viz., phenyl acetaldehyde, benzaldehyde and 2-phenyl ethanol were prepared in single and combinations and field tested using three trap designs (funnel trap, sleeve trap and water trap) for trapping of lepidopteran pests in castor.

Results : Phenyl acetaldehyde elicited strongest EAG responses for female and male moths of $S$. litura ( -1.518 to $-2.221 \mathrm{mV}$ and -1.756 to $-2.214 \mathrm{mV}$, respectively). Female and male moths of $A$. janata showed significantly greater EAG responses to benzaldehyde $(-2.573$ to $-3.336 \mathrm{mV}$ and -2.377 to $-3.396 \mathrm{mV}$, respectively). The highest EAG responses of female and male moths of $C$. punctiferalis were elicited by 2-phenylethanol (-2.563 to $-3.152 \mathrm{mV}$ and -2.475 to $-2.903 \mathrm{mV}$, respectively). In field experiment, water trap baited with phenyl acetaldehyde + 2-phenyl ethanol recorded significantly higher moth catches of $S$. litura (6.8 moths/trap/wk) and C. punctiferalis (5.8 moths/trap/wk).

Monitoring and management of lepidopteran pests of castor

Evaluation of attractiveness of synthetic kairomones against lepidopteran pests (tobacco caterpillar, semilooper and capsule borer)
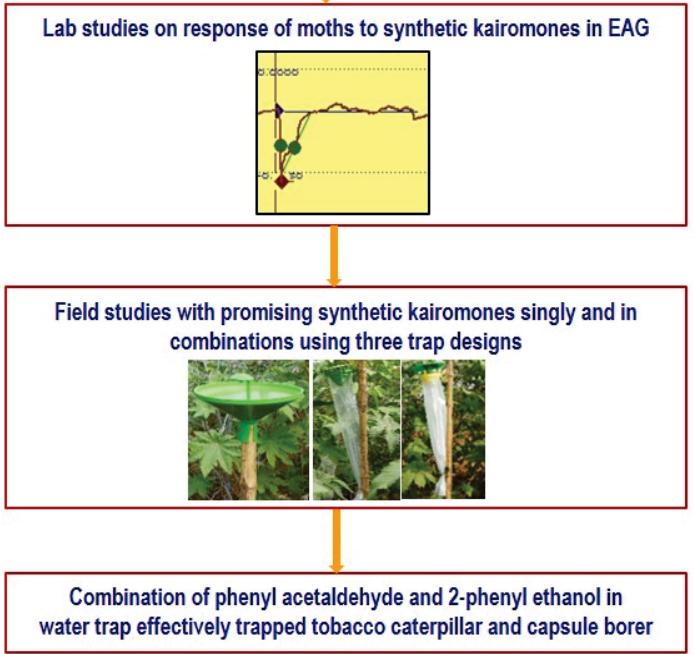

Interpretation : Combination of phenyl acetaldehyde and 2-phenyl ethanol in water trap can be used for monitoring of the lepidopteran pests in castor. The synthetic attractants has potential in developing management methods such as mass trapping or 'attract and kill system' for the lepidopteran pests of castor. 


\section{Introduction}

Castor (Ricinus communis L.) is an industrially important oilseed crop. Its seed oil has multifarious applications in production of a wide range of industrial products viz., dyes, detergents, plastics, printing ink, linoleum, patent leather, ointment, polishes, surface paints, adhesives, lubricants and hydraulic fluids. India has $70 \%$ of world area with $87 \%$ of the total world production in castor (Sarada et al., 2015). The current castor production in the country is 17.33 lakh tonnes from 11.05 lakh ha with a productivity of $1568 \mathrm{~kg} \mathrm{ha}^{-1}$ (Anonymous, 2016). Though castor productivity in India is more than the world average, there are several production constraints in the traditional rainfed castor growing areas of South India, among which insect pests and diseases dominate the scenario. A large number of insect pests are recorded on castor at different phenological stages of the crop, but damage due to lepidopteran pests viz., tobacco caterpillar, Spodoptera litura F. (Noctuidae: Lepidoptera); semilooper, Achaea janata L. (Noctuidae: Lepidoptera) and capsule borer, Conogethes punctiferalis Guenee (Pyralidae: Lepidoptera) are of greater economic importance. The avoidable yield losses due to insect pests on castor cultivars ranged from 17.2 to $63.3 \%$ during kharif season (Lakshminarayana and Duraimurugan, 2014).

So far, the use of synthetic insecticides has been a major approach for controlling these pests. However, the indiscriminate and injudicious use of wide spectrum insecticides induced insecticide resistance in insects, pest resurgence, toxic effect on non target organisms including natural enemies and environmental pollution (Lakshminarayana and Raoof, 2005; Singh et al., 2017). Developing a new environmentally benign alternative monitoring and management system for these pests may reduce the frequency of application of insecticides and impact on the environment. Sex pheromones of lepidopteran pests have been widely used for monitoring, however they are species specific and attract only males. Further improvement in monitoring and management of these pests might be achieved with traps that attract females or both sexes. Since lepidopteran moths are highly attracted to the volatile cues present in the floral parts of host plants for both ovipositing and nectar feeding, this could be used as the basis for monitoring or management strategy (Burguiere et al., 2001). In the recent years, kairomones, a type of semiochemicals which include the chemical volatiles emitted by plants have been experimentally demonstrated as attractants for trapping of several lepidopterans (Toth et al., 2010; Landolt et al., 2011). Management by 'lure and kill' using floral chemicals or synthetic kairomonal attractants have been experimentally demonstrated as an effective method to attract lepidopteran pest moth species in agricultural crops (Camelo et al., 2007; Gregg et al., 2010). Such kind of basic information on behavioural and electrophysiological responses of major lepidopteran pests of castor to floral chemicals or synthetic kairomones needs to be generated to develop behaviour based strategy for effective monitoring or management. Hence, the current study was undertaken to ascertain the electrophysiological responses of the female and male moths of S. litura, A. janata and C. punctiferalis to the selected synthetic kairomones under laboratory conditions and their effectiveness for catching of the moths under field conditions in castor.

\section{Materials and Methods}

Test insects : Larvae of tobacco caterpillar, Spodoptera litura; semilooper, Achaea janata and capsule borer, Conogethes punctiferalis collected during rainy seasons (July to November, 2012 and 2013) from castor fields at Research Farm, ICARIndian Institute of Oilseeds Research, Rajendranagar, Hyderabad were used to initiate the mass culturing. The larvae of $S$. litura and $A$. janata were mass reared in laboratory on castor leaves (cv. VP1). The larvae of $C$. punctiferalis were reared on fresh castor capsules (cv. DCS-9) in Insect Breeding Dish (90 x 40 $\mathrm{mm}$ with air hole size of $40 \mathrm{~mm}$, HiMedia, Mumbai). The larvae were provided with fresh capsules once in 3-4 days. After pupation, the sex of the pupae of all three species was determined on the basis of morphological features seen on the ventral side of abdomen. In female pupae, a median shallow furrow is on the VIII sternum. A medium groove surrounded by pad-like circular area is seen on the midventral side of IX segment on male pupae. Male and female pupae were transferred to individual specimen tubes (25 x $100 \mathrm{~mm}$, Borosil, Mumbai) for adult emergence and the mouth of the tube was covered with a black muslin cloth. Adults were fed with $10 \%$ sucrose solution absorbed on a cotton pad. The required numbers of male and female moths for different experiments were taken from the culture. All experiments and mass rearing were carried out under ambient $\left(27 \pm 2^{\circ} \mathrm{C}, 60-70 \% \mathrm{RH}\right)$ conditions with natural photoperiod (12:12L:D).

Test compounds : Six synthetic kairomonal attractants viz., benzaldehyde, benzyl acetate, $p$-anisaldehyde, phenyl acetaldehyde, 2-phenyl ethanol (Sigma-Aldrich, India) and methyl salicylate (HiMedia Laboratories Pvt. Ltd., Mumbai) were selected on the basis of a bibliographic search for compounds identified as attractants of lepidopteran moths.

Electroantennography (EAG) : Electophysiological response of one-day-old male and female moths of $S$. litura, $A$. janata and $C$. punctiferalis to selected six synthetic kairomones along with air (as check) was determined by electroantennographic system (Syntech, Hilversum, Netherlands) using completely randomized design. Test compounds were subjected to EAG by applying at two different concentrations $(0.1 \mu \mathrm{l}$ and $1 \mu \mathrm{l})$. Three replications with five adults each were observed. Antennal response to the compounds in negative milliVolts was recorded.

Field tests : Lures of three synthetic kairomonal attractants found promising in the EAG (benzaldehyde, phenyl acetaldehyde and 2-phenyl ethanol) were prepared in single and combinations. Yellow Silicone septa (Sun Lure, Chennai, India) were used in the experiment. Septa were first ultrasonicated for $6 \mathrm{hr}$ in hexane and then extracted three times with hexane for a total of $24 \mathrm{hr}$, and air- 


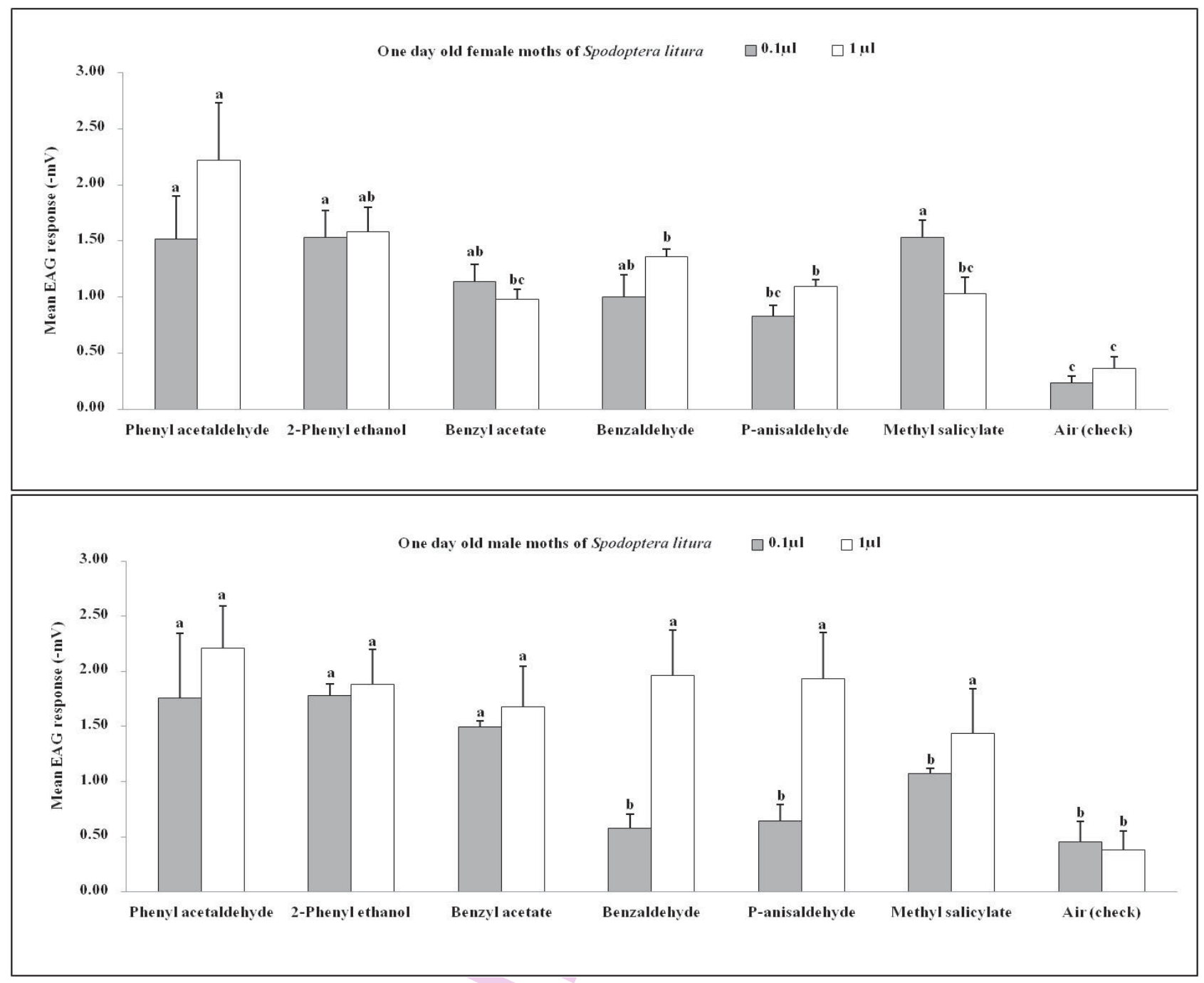

Fig. 1A: Electroantennographic response of tobacco caterpillar, Spodoptera litura to synthetic kairomone attractants. Bars marked by the same letter are not significantly different (LSD test; $P=0.05)$

dried in a fume hood for $48 \mathrm{hrs}$ before loading (Kovanci et al., 2006). Septa were impregnated with $100 \mu$ of synthetic kairomones, while $100 \mu$ leach of the chemicals was loaded for preparing combination lures viz., benzaldehyde + phenyl acetaldehyde, benzaldehyde +2 -phenyl ethanol and phenyl acetaldehyde + 2-phenyl ethanol. Hexane $(25 \mu \mathrm{l})$ was added in all the lures to aid in the penetration of chemicals into the silicone septa. Septa were stored at $-20^{\circ} \mathrm{C}$ until further use.

Six synthetic kairomone loaded lures were evaluated using three trap designs viz., funnel trap (Fero-T®, PCI Pvt. Ltd., Hyderabad, India), sleeve trap (Phero-Sensor ${ }^{\mathrm{TM}}$, Pheromone Chemicals, Hyderabad, India) and water trap (Wota-T®, PCI Pvt. Ltd., Hyderabad, India) in factorial randomized block design with three replications. Traps with septa not containing any synthetic kairomones were used as control. The field test was performed in a castor field (2 acre) at Research Farm, ICAR-Indian Institute of Oilseeds Research, Rajendranagar, Hyderabad. The experiment was carried out during the active period of occurrence of all the three lepidopteran pests (September to October, 2014) coinciding with vegetative and primary spike development stage of the crop. The traps were randomly distributed equidistantly with $50 \mathrm{~m}$ between them and placed $0.5 \mathrm{~m}$ above canopy height. Traps were monitored once a week from mid September to mid October (standard weeks from 38 to 41) and the lures were changed once in two weeks. The number of $S$. litura, $A$. janata and $C$. punctiferalis moths caught per week for each individual trap was recorded and were removed from the trap. Mean moth catches per trap per week of the 4-week trapping period was used for statistical analysis.

Statistical analysis : Data were analyzed statistically using AGRES statistical software. EAG data were subjected to analysis of variance (ANOVA) and differences in pairs of means between treatments were separated using least significant difference (LSD). For field experiment, square root transformed data was 
subjected to analysis of variance. Original data is shown in the table. Following ANOVA, differences between datasets were determined using $L S D$ at $P=0.05$ at all instances.

\section{Results and Discussion}

The mean EAG response of one-day-old female and male moths of tobacco caterpillar, $S$. litura to synthetic kairomones at two concentrations $(0.1$ and $1 \mu \mathrm{l})$ is shown in Fig. $1 \mathrm{~A}$. In both the concentrations, significantly highest EAG response of female moths were elicited by phenyl acetaldehyde $(-1.518$ and $-2.221 \mathrm{mV}$ at a concentration of 0.1 and $1 \mu \mathrm{l}$, respectively) and 2-phenylethanol (-1.531 and $-1.578 \mathrm{mV}$ at 0.1 and $1 \mu \mathrm{l}$, respectively) as compared to other synthetic kairomones $(-0.827$ to $-1.534 \mathrm{mV})$. The response of one-dayold male moths at lower concentration $(0.1 \mu \mathrm{l})$ were very high to 2-phenylethanol (-1.779 mV) and phenyl acetaldehyde (-1.756 $\mathrm{mv})$. At higher concentration $(1 \mu \mathrm{l})$, the male response to phenyl acetaldehyde was found to be very high $(-2.214 \mathrm{mV})$ but did not differ significantly with other compounds (-1.435 to $-1.962 \mathrm{mV}$ ).

Synthetic kairomones at both the concentrations evoked significantly greater EAG responses in semilooper, $A$. janata (Fig. $1 B)$. The highest EAG responses of one-day-old female moths were elicited by benzaldehyde $(-2.573$ and $-3.336 \mathrm{mV}$ at $\mathrm{a}$ concentration of 0.1 and $1 \mu \mathrm{l}$, respectively). It was followed by $2-$ phenylethanol (-2.160 and $-2.867 \mathrm{mV}$ at 0.1 and $1 \mu$, respectively) and phenyl acetaldehyde (-1.739 and $-2.598 \mathrm{mV}$ at 0.1 and $1 \mu \mathrm{l}$, respectively) exhibited significantly larger response as compared to other synthetic kairomones $(-1.350 \mathrm{mV}$ to $-2.271 \mathrm{mV})$ and air check ( -0.113 to $-0.215 \mathrm{mV})$. Similarly, one-day-old male moths also showed significantly greater EAG responses to

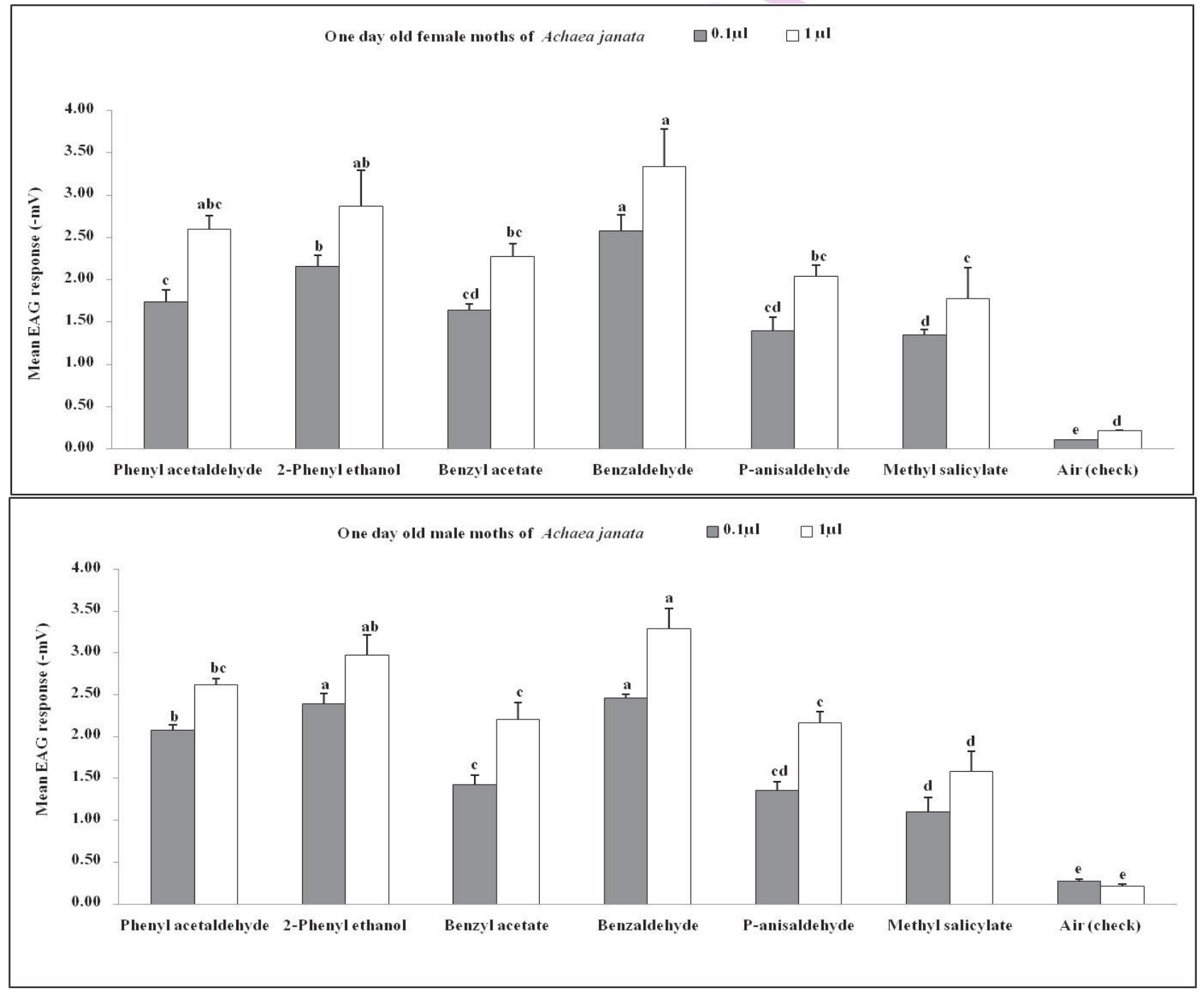

Fig. 1B : Electroantennographic response of semilooper, Achaea janata to synthetic kairomone attractants. Bars marked by same letter are not significantly different (LSD test; $P=0.05$ ) 

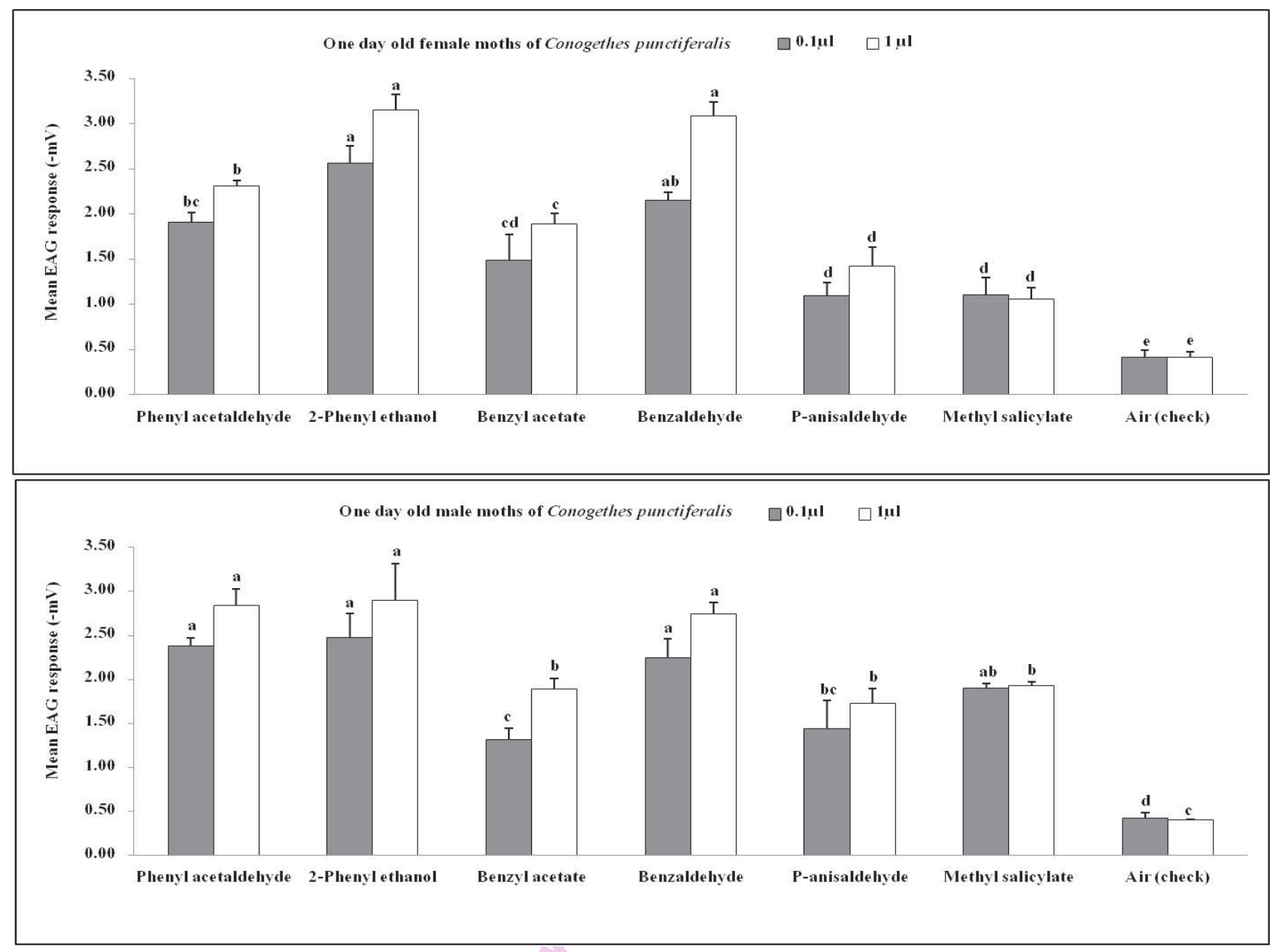

Fig. 1C : Electroantennographic response of capsule borer, Conogethes punctiferalis to synthetic kairomone attractants. Bars marked by same letter are not significantly different ( $L S D$ test; $P=0.05)$

benzaldehyde (-2.459 and $-3.294 \mathrm{mV}$ at a concentration of 0.1 and $1 \mu \mathrm{l}$, respectively) followed by 2-phenylethanol (-2.393 and -2.97 $\mathrm{mV}$ at 0.1 and $1 \mu$, respectively) and phenyl acetaldehyde (-2.072 and $-2.623 \mathrm{mV}$ at 0.1 and $1 \mu \mathrm{l}$, respectively).

For synthetic kairomones evaluated, there was a significant difference on the EAG response of capsule borer, $C$. punctiferalis in both the concentrations (Fig. 1C). It was observed that the response of one-day-old female moths was significantly very high to 2-phenylethanol $(-2.563$ and $-3.152 \mathrm{mV}$ at a concentration of 0.1 and $1 \mu$, respectively) and found on par with benzaldehyde $(-2.152$ and $-3.089 \mathrm{mV}$ at 0.1 and $1 \mu \mathrm{l}$, respectively). It was followed by phenyl acetaldehyde (-1.906 and $-2.309 \mathrm{mV}$ at 0.1 and $1 \mu \mathrm{l}$, respectively) that showed larger response as compared to other synthetic kairomones $(-1.063 \mathrm{mV}$ to $-1.893 \mathrm{mV})$. Highest EAG responses of one-day-old male moths were elicited by 2-phenylethanol $(-2.475$ and $-2.903 \mathrm{mV}$ at 0.1 and $1 \mu \mathrm{l}$, respectively), phenyl acetaldehyde (-2.381 and $2.839 \mathrm{mV}$ at 0.1 and $1 \mu \mathrm{l}$, respectively) and benzaldehyde (-2.248 and $-2.744 \mathrm{mV}$ at 0.1 and $1 \mu$ l, respectively) as compared to other synthetic kairomones (-1.317 to-1.930 mV) (Fig. 1C).
More than 16 species of lepidopteran insect pests are reported to damage castor in India. However, tobacco caterpillar, S. litura (Noctuidae: Lepidoptera); semilooper, A. janata (Noctuidae: Lepidoptera) and capsule borer, C. punctiferalis (Pyralidae: Lepidoptera) are major lepidopteran species of regular occurrence and causing considerable yield loss in castor (Lakshminarayana and Duraimurugan, 2014.). Male and female moth attraction to and feeding from blooming plants has been noted for several lepidopteran pest species (Guedot et al., 2008). Floral chemicals or synthetic kairomones have been experimentally demonstrated as attractants for trapping several lepidopteran species (Meagher and Landolt, 2010; Toth et al., 2010). In order to identify the synthetic kairomones or floral chemicals that elicit attraction from major lepidopteran pests of castor, a method of screening is required. This could be achieved by using electroantennography (EAG), a technique developed for the identification of lepidopterous sex pheromones and successfully adapted for use in identifying a wide range of kairomones. As a prelude, the current study was undertaken to identify promising synthetic kairomonal attractants for major lepidopteran pests of castor. EAG response of tobacco caterpillar, 
Table 1: Mean number of pest moth species captures in different traps designs baited with synthetic kairomones singly and their combinations in castor ecosystem (Kharif, 2014)

\begin{tabular}{|c|c|c|c|c|c|c|c|c|}
\hline \multirow[b]{2}{*}{ Synthetic Kairomones } & \multicolumn{4}{|c|}{ No. of S. litura moths/trap/wk ${ }^{\#}$} & \multicolumn{4}{|c|}{ No. of C. punctiferalis moths/trap/wk } \\
\hline & Funnel trap & Sleeve trap & Water trap & Mean & Funnel trap & Sleeve trap & Water trap & Mean \\
\hline Benzaldehyde & $\begin{array}{l}0.08 \\
(0.76)^{d}\end{array}$ & $\begin{array}{l}0.00 \\
(0.71)^{d}\end{array}$ & $\begin{array}{l}0.17 \\
(0.81)^{d}\end{array}$ & $\begin{array}{l}0.08 \\
(0.76)^{\circ}\end{array}$ & $\begin{array}{l}0.00 \\
(0.71)^{\mathrm{e}}\end{array}$ & $\begin{array}{l}0.00 \\
(0.71)^{\mathrm{e}}\end{array}$ & $\begin{array}{l}0.00 \\
(0.71)^{\mathrm{e}}\end{array}$ & $\begin{array}{l}0.00 \\
(0.71)^{d}\end{array}$ \\
\hline Phenyl acetaldehyde & $\begin{array}{l}0.08 \\
(0.76)^{d}\end{array}$ & $\begin{array}{l}1.00 \\
(1.21)^{\mathrm{c}}\end{array}$ & $\begin{array}{l}1.00 \\
(1.21)^{\mathrm{c}}\end{array}$ & $\begin{array}{l}0.69 \\
(1.07)^{b}\end{array}$ & $\begin{array}{l}0.00 \\
(0.71)^{\mathrm{e}}\end{array}$ & $\begin{array}{l}0.08 \\
(0.76)^{e}\end{array}$ & $\begin{array}{l}0.25 \\
(0.86)^{\mathrm{e}}\end{array}$ & $\begin{array}{l}0.11 \\
(0.78)^{\text {cd }}\end{array}$ \\
\hline 2-Phenyl ethanol & $\begin{array}{l}0.17 \\
(0.80)^{d}\end{array}$ & $\begin{array}{l}1.08 \\
(1.25)^{\mathrm{c}}\end{array}$ & $\begin{array}{l}0.83 \\
(1.15)^{\mathrm{c}}\end{array}$ & $\begin{array}{l}0.69 \\
(1.07)^{b}\end{array}$ & $\begin{array}{l}0.17 \\
(0.81)^{\mathrm{e}}\end{array}$ & $\begin{array}{l}0.75 \\
(1.12)^{\mathrm{dd}}\end{array}$ & $\begin{array}{l}1.08 \\
(1.25)^{c}\end{array}$ & $\begin{array}{l}0.67 \\
(1.06)^{b}\end{array}$ \\
\hline $\begin{array}{l}\text { Benzaldehyde + Phenyl } \\
\text { acetaldehyde }\end{array}$ & $\begin{array}{l}0.00 \\
(0.71)^{d}\end{array}$ & $\begin{array}{l}0.17 \\
(0.80)^{d}\end{array}$ & $\begin{array}{l}0.50 \\
(0.88)^{d}\end{array}$ & $\begin{array}{l}0.22 \\
(0.80)^{c}\end{array}$ & $\begin{array}{l}0.00 \\
(0.71)^{\mathrm{e}}\end{array}$ & $\begin{array}{l}0.08 \\
(0.76)^{e}\end{array}$ & $\begin{array}{l}0.08 \\
(0.76)^{\mathrm{e}}\end{array}$ & $\begin{array}{l}0.05 \\
(0.74)^{d}\end{array}$ \\
\hline $\begin{array}{l}\text { Benzaldehyde + } \\
\text { 2-Phenyl ethanol }\end{array}$ & $\begin{array}{l}0.00 \\
(0.71)^{d}\end{array}$ & $\begin{array}{l}0.25 \\
(0.84)^{d}\end{array}$ & $\begin{array}{l}0.08 \\
(0.76)^{d}\end{array}$ & $\begin{array}{l}0.11 \\
(0.77)^{\mathrm{c}}\end{array}$ & $\begin{array}{l}0.17 \\
(0.81)^{e}\end{array}$ & $\begin{array}{l}0.42 \\
(0.94)^{\mathrm{de}}\end{array}$ & $\begin{array}{l}0.33 \\
(0.91)^{\mathrm{de}}\end{array}$ & $\begin{array}{l}0.31 \\
(0.89)^{\mathrm{c}}\end{array}$ \\
\hline $\begin{array}{l}\text { Phenyl acetaldehyde + } \\
\text { 2-Phenyl ethanol }\end{array}$ & $\begin{array}{l}3.58 \\
(2.02)^{b}\end{array}$ & $\begin{array}{l}2.83 \\
(1.82)^{b}\end{array}$ & $\begin{array}{l}6.75 \\
(2.69)^{\mathrm{a}}\end{array}$ & $\begin{array}{l}4.39 \\
(2.18)^{\mathrm{a}}\end{array}$ & $\begin{array}{l}1.08 \\
(1.25)^{c}\end{array}$ & $\begin{array}{l}2.33 \\
(1.67)^{b}\end{array}$ & $\begin{array}{l}5.75 \\
(2.47)^{\mathrm{a}}\end{array}$ & $\begin{array}{l}3.05 \\
(1.80)^{\mathrm{a}}\end{array}$ \\
\hline Control & $\begin{array}{l}0.00 \\
(0.71)^{d}\end{array}$ & $\begin{array}{l}0.00 \\
(0.71)^{d}\end{array}$ & $\begin{array}{l}0.00 \\
(0.71)^{d}\end{array}$ & $\begin{array}{l}0.00 \\
(0.71)^{\circ}\end{array}$ & $\begin{array}{l}0.00 \\
(0.71)^{\mathrm{e}}\end{array}$ & $\begin{array}{l}0.00 \\
(0.71)^{e}\end{array}$ & $\begin{array}{l}0.00 \\
(0.71)^{\mathrm{e}}\end{array}$ & $\begin{array}{l}0.00 \\
(0.71)^{d}\end{array}$ \\
\hline Mean & $\begin{array}{l}0.56 \\
(0.92)^{c} \\
\text { F-test }\end{array}$ & $\begin{array}{l}0.76 \\
(1.05)^{b} \\
\text { SEm } \pm\end{array}$ & $\begin{array}{l}1.33 \\
(1.17)^{\mathrm{a}} \\
C D(P=0.05)\end{array}$ & & $\begin{array}{l}0.20 \\
(0.82)^{c} \\
\text { F-test }\end{array}$ & $\begin{array}{l}0.52 \\
(0.95)^{b} \\
\text { SEm } \pm\end{array}$ & $\begin{array}{l}1.07 \\
(1.09)^{\mathrm{a}} \\
C D(P=0.05)\end{array}$ & \\
\hline Synthetic kairomones (K) & * & 0.06 & 0.13 & & * & 0.07 & 0.14 & \\
\hline Trap designs $(\mathrm{T})$ & * & 0.04 & 0.08 & & * & 0.05 & 0.09 & \\
\hline Interaction $(\mathrm{K} \times \mathrm{T})$ & * & 0.11 & 0.23 & & * & 0.12 & 0.24 & \\
\hline
\end{tabular}

Figures in parentheses are square root transformed values; Different letters on the same column indicate significant differences (LSD test; $P=0.05)$. ${ }^{\#}$ Mean moth catches per trap per wk from 17 September to 14 October, 2014

semilooper, capsule borer to six synthetic kairomonal attractants showed significant hypersensitive reaction to 2-phenylethanol, benzaldehyde and phenyl acetaldehyde. In general, the absolute EAG response reflects the number of activated receptor neurons and their degree of activation. Earlier, Landolt et al. (2011) have reported attraction of several lepidopteran pest moth species to phenylethanol, phenyl acetaldehyde and benzaldehyde. These synthetic attractants are commonly released by the nightblooming plants, which may be reason for higher response of the noctuid and pyralid moths to these compounds.

The three synthetic kairomones viz., benzaldehyde, phenyl acetaldehyde and 2-phenyl ethanol that elicited the strongest EAG responses for the lepidopteran pests of castor ( $S$. litura, $A$. janata and $C$. punctiferalis) were tested in single and in combinations under field conditions using three trap designs. Data on the mean number of pest moth species captured in different trap designs baited with synthetic kairomones in castor ecosystem are presented in Table 1. During field experimentation, two pests viz., S. litura and $C$. punctiferalis were attracted in significant numbers, while there was no attraction of $A$. janata. Among synthetic kairomones tested a combination of phenyl acetaldehyde + 2-phenyl ethanol baited traps captured significantly higher moths of $S$. litura (4.39 moths/trap/wk) and $C$. punctiferalis (3.05 moths/trap/wk) as compared to traps baited with the synthetic kairomones alone or in other combinations
(0.08 to 0.69 moths/trap/wk of $S$. litura and 0.0 to 0.67 moths/trap/wk of C. punctiferalis). Among three trap designs tested, water traps attracted significantly more number of $S$. litura (1.33 moths/trap/wk) and C. punctiferalis (1.07 moths/trap/wk) as compared to sleeve ( 0.76 and 0.52 moths/trap/wk of $S$. litura and C. punctiferalis, respectively) and funnel traps (0.56 and 0.20 moths/trap/wk of S. litura and C. punctiferalis, respectively). Statistical analysis revealed that interaction between synthetic kairomones and trap designs were found significant. Among the treatment combinations, water trap baited with phenyl acetaldehyde + 2-phenyl ethanol recorded significantly higher moth catches of $S$. litura (6.8 moths/trap/wk) and C. punctiferalis (5.8 moths/trap/wk) as compared to other treatments ( 0.0 to 3.58 and 0.0 to 2.33 moths/trap/wk of S. litura and C. punctiferalis, respectively) and unbaited control traps (nil moth catches).

Monitoring of pest population is an essential component of integrated pest management. Lepidopteran pest population in agricultural crops are monitored by capturing males in traps baited with synthetically-produced female pheromones. However, sex pheromones are highly species-specific and attract only males (Burguiere et al., 2001). Floral chemicals or synthetic kairomones are attractive to adult moths of both sexes, and thus have advantages over sex pheromones that catch only males. Hence, these chemicals can be used to enhance monitoring tools for a wide range of insect pests, lure moths away from host plants 
or removal of insects from field by "attract-and-kill" system and control populations through mass trapping (Meagher, 2002; Landolt et al., 2011). In the present study, preliminary field trapping experiment with three synthetic kairomones (2phenylethanol, benzaldehyde and phenyl acetaldehyde) single and in combinations revealed that the combination of phenyl acetaldehyde + 2-phenyl ethanol baited traps captured significantly higher moths of $S$. litura and $C$. punctiferalis as compared to these chemicals tested single or in combinations. The results are in consonance with Landolt et al. (2011) who found significantly higher moth catches of true armyworm, Mythimna unipuncta (Lepidoptera: Noctuidae) in traps baited with phenylacetaldehyde + 2-phenylethanole as compared to these chemicals used alone. This also corroborates with the reports of Meagher and Landolt (2008) who reported combination of phenylacetaldehyde + methyl salicylate trapped $76 \%$ higher moth catches of soybean looper, Chrysodeixis includens (Lepidoptera: Noctuidae) as compared to phenylacetaldehyde alone. Based on these results, it is postulated that combination of phenylacetaldehyde +2 -phenylethanole has potential to use in monitoring or management of lepidopteran pests of castor by mass trapping or luring and killing approaches.

\section{Acknowledgments}

The authors thank the Director, ICAR-Indian Institute of Oilseeds Research, Hyderabad for providing necessary facilities for carrying out the work and Director, ICAR-Indian Institute of Rice Research, Hyderabad for providing electroantennogram facility.

\section{References}

Anonymous: Directorate of Economics and Statistics. Department of Agriculture, Cooperation and Farmers Welfare, Ministry of Agriculture and Farmers Welfare, Government of India (2016).

Burguiere, L., F. Marion-Poll and A. Cork : Electrophysiological responses of female Helicoverpa armigera (Hubner) (Lepidoptera; Noctuidae) to synthetic host odours. J. Insect Physiol., 47, 509-514 (2001).
Camelo, L.D.A., P.J. Landolt and R.S. Zack: A kairomone based attractand-kill system effective against alfalfa looper (Lepidoptera: Noctuidae). J. Econ. Entomol., 100, 366-374 (2007).

Gregg, P.C., A.P. Del Socorro and G.S. Henderson: Development of a synthetic plant volatile-based attracticide for female noctuid moths. II. Bioassays of synthetic plant volatiles as attractants for the adults of the cotton bollworm, Helicoverpa armigera (Hubner) (Lepidoptera: Noctuidae). Aust. J. Entomol., 49, 21-30 (2010).

Guedot, C., P.J. Landolt and C.L. Smithhisler: Odorants of the flowers of butterfly bush, Buddleia davidii, as possible attractants of pest species of moths. Florida Entomol., 91, 576-582 (2008).

Lakshminarayana, M. and P. Duraimurugan: Assessment of avoidable yield losses due to insect pests in castor (Ricinus communis L.). J. Oilseeds Res., 31, 140-144 (2014).

Lakshminarayana, M. and M.A. Raoof: Insect pests and diseases of castor and their management. Directorate of Oilseeds Research, Hyderabad, India (2005).

Landolt, P.J., E. Jang, L. Carvalho and P. Michael: Attraction of pest moths (Lepidoptera: Noctuidae, Crambidae) to floral lures on the Island of Hawaii. Proceedings of Hawaiian Entomological Society, 43, 49-58 (2011).

Meagher, R.L.: Trapping noctuid moths with synthetic floral volatile lures. Entomol. Exp. Appl., 103, 219-226 (2002).

Meagher, R.L. and P.J. Landolt: Attractiveness of binary blends of floral odorant compounds to moths in Florida, USA (Lepidoptera: Noctuidae; Pyralidae). Entomol. Exp. Appl., 128, 323-329 (2008).

Meagher, R.L. and P.J. Landolt: Binary floral lure attractive to velvetbean caterpillar adults (Lepidoptera: Noctuidae). Florida Entomol., 93, 73-79 (2010).

Kovanci, O.B., C. Schal, J.F. Walgenbach and G.G. Kennedy: Effects of pheromone loading, dispenser age, and trap height on pheromone trap catches of the oriental fruit moth in apple orchards. Phytoparasitica, 34, 252-260 (2006).

Sarada, C., K. Alivelu, V. Sambasiva Rao, S.N. Sudhakara Babu and K.S. Varaprasad: Oilseeds Statistics -A Compendium 2015. ICAR-Indian Institute of Oilseeds Research, Hyderabad, India, p. 956 (2015).

Singh, S., D.K. Sharma, S. Bhatia and A. Singh: Effect of various plant powders on rice weevil (Sitophilus oryzae Linn.) in stored wheat. J. Environ. Biol., 38, 501-508 (2017).

Toth, M., I.B. Szarukan, A. Dorogi, P.N. Gulyas and Z. Rozgonyi: Male and female noctuid moths attracted to synthetic lures in Europe. $J$. Chem. Ecol., 36, 592-598 (2010). 